\title{
AN URGENT SUGGESTION TO POUR OLD WINE INTO NEW BOTTLES COMMENT ON “A NEW JURISPRUDENTIAL FRAMEWORK FOR JURISDICTION”
}

\author{
Cedric Ryngaert*
}

Dan Svantesson is quickly establishing himself as a leading voice in the field of jurisdiction. Coming to this field from Internet and data protection law, he is surely well placed to criticize the current legal framework of international jurisdiction in light of technological evolution, which has made territoriality lose its salience as the cornerstone of jurisdiction. I myself have recently been characterized as one of the border guards of territoriality, ${ }^{1}$ on the basis of my earlier monograph on Jurisdiction in International Law. ${ }^{2}$ Accordingly, the informed reader might believe that I will severely criticize as iconoclastic such a proposal as Svantesson's, namely doing away with territoriality as the very linchpin of jurisdiction. As it happens, however, I largely concur with Svantesson's ideas, at least to the extent they apply to cross-border transactions via the Internet. In this contribution, I argue that the reality of a de-territorialized Internet necessitates jurisdictional rethinking, but that this rethinking in fact heavily relies on previous scholarship, predating the Internet era. The advent of the current era, however, has lent particular urgency to those earlier proposals.

\section{The De-Territorialization Of The Internet And Its Jurisdictional Consequences}

There is no denying that the arrival of the Internet has dramatically changed spatiotemporal realities and even collapsed them altogether, as data can be moved from one jurisdiction to another with the click of a mouse. It is understandable that territoriality no longer serves a useful purpose in this constellation. While data could still technically be linked to a territory-indeed, this is how the EU Data Protection Directive and the future General Data Protection Regulation jurisdictionally operate ${ }^{3}$ - their territorial presence may be of only an incidental or passing nature. Moreover, as Internet corporations, intermediaries, data controllers, etc. have a global reach (cyberspace having no physical borders), their activities may produce effects in a large number of states (in all states where they collect data from individual persons and in all states where harmful content is accessed). On the basis of the territorial effects principle, all these states may have jurisdiction. This situation may obviously give rise to normative conflicts between states and may considerably increase transaction costs for private operators who have to comply with the laws of multiple jurisdictions. The jurisdictional exclusivity

* Professor of Public International Law, Utrecht University. The author appreciates the financial support from the European Research Council (Proposal 336230 - UNIJURIS) and the Dutch Organization for Scientific Research (No. 016.135.322).

Originally published online 03 November 2015.

${ }^{1}$ Carl Landauer, The Ever-Ending Geography of International Law: The Changing Nature of the International System and the Challenge to International Law: A Reply to Daniel Bethlehem, 25 Eur. J. INT"L L. 31 (2014).

${ }^{2}$ CEDRIC RYNGAERT, JuRISDICTION IN INTERNATIONAL LAW (2nd ed. 2015).

${ }^{3}$ Directive 95/46/EC of the European Parliament and of the Council of 24 October 1995 on the protection of individuals with regard to the processing of personal data and on the free movement of such data, art. 4, 1995 O.J. (L 281) 31; Proposal for a Regulation of the European Parliament and of the Council on the protection of individuals with regard to the processing of personal data and on the free movement of such data, art. 3, COM (2012) 011 final (Jan. 25, 2012).

ASIL and Cedric Ryngaert (C) 2015 
on which Westphalian territoriality was originally premised — with the sovereign promulgating laws for subjects within and only within his territory, to the exclusion of other sovereigns-loses all its salience here.

\section{Old Wine In New Bottles?}

Svantesson proposes to replace territoriality with a three-pronged test based on substantial connection, legitimate interest, and reasonableness. In all fairness, these criteria are hardly new. In fact, as Svantesson recognizes, they feature prominently in Section 403 of the U.S. Restatement (Third) of U.S. Foreign Relations Law. However, what is new is that he upgrades these criteria to first-order jurisdictional criteria. In contrast, under Section 403 they only operate as second-order tests which mitigate the potential jurisdictional overreach which the classic first-order permissive jurisdictional principles listed in the preceding Section 402_territoriality, personality, security, universality - may yield. Put differently, in the classic view, connection/interest/reasonableness only come into play once an assertion can be preliminarily be justified on the basis of a traditional permissive principle, in particular territoriality. In Svantesson's approach, we skip the first step and directly apply his core principles of connection/interest/reasonableness_-for which the classic jurisdictional grounds are arguably just proxies anyway. There is merit in this approach, insofar as in the globally interconnected world, states will nearly always find a territorial nexus, however weak, to establish their jurisdiction over harmful activity. Territoriality can then no longer serve as a defensible principle of jurisdictional order. ${ }^{4}$

The insight about the ordering potential of territoriality is not novel either, and it has not specifically been triggered by the advent of the current information and communication technology. It is recalled that the origins of Section 403, while having a general, subject-matter neutral content, can be found in attempts by U.S. courts in the 1970s to limit the scope of the territorial effects principle in the antitrust field. ${ }^{5}$ These attempts stemmed from dissatisfaction with the ordering role of territoriality in an economically interconnected world, where global antitrust conspiracies could have effects everywhere, thus triggering the jurisdiction of multiple sovereigns and potentially leading to international discord. The parallel with the current debates regarding Internet regulation and data protection is striking.

Also, the motivating question-whether a state can issue a warrant authorizing the search and seizure of information associated with a specified web-based e-mail account stored abroad-is hardly new. In his piece, Svantesson sets great store by nonterritorial solutions to this question, which sits astride prescriptive and enforcement jurisdiction, and is central to the ongoing litigation between U.S. authorities and Microsoft. The controversy over the legality and appropriateness of such a warrant echoes, and not just faintly, the transatlantic controversy of the 1970s and 1980s over the presumed extraterritoriality of U.S. discovery orders, which even led to blocking legislation in Europe. ${ }^{6}$ The only difference is that the controversy at the time related to physical documents, and now it relates to virtual data. Then, just like now, the U.S. Government considered its orders for the production of documents held abroad by a person subject to U.S. jurisdiction to be based on the territorial principle. ${ }^{7}$ Then, just as now, Europeans consider such orders as extraterritorial and a violation of their sovereignty. ${ }^{8}$ It may appear that there is nothing new under the sun. Perhaps the only exception may be the

${ }^{4}$ Cedric Ryngaert, Whither Territoriality? The European Union's Use of Territoriality to Set Norms with Universal Effects, in WHAT's WRONG WITH INTERNATIONAL LAW 434 (Cedric Ryngaert et al. eds., 2015).

5 Timberlane Lumber Co. v. Bank of America, 549 F.2d 597 (9th Cir. 1976); Mannington Mills v. Congoleum Corp., 595 F.2d 1287 (3d Cir. 1979).

${ }^{6}$ Protection of Trading Interests Act 1980, c. 11 (U.K.).

${ }^{7}$ David J. Gerber, Extraterritorial Discovery and the Conflict of Procedural Systems: Germany and the United States, 34 AM. J. COMP. L. 745,776 (1986).

${ }^{8} \underline{I d}$. at 778 . 
technological option to remotely access data or evidence located abroad. Whereas, in the past, authorities could only subpoena a person subject to its jurisdiction (hoping that this threat would coerce him to submit the requested documents even if he were subject to rules legally precluding him from doing so), now authorities possessing advanced technology may bypass both the person and the foreign state and remotely access data via hacking or spyware techniques. ${ }^{9}$

Old wine in new bottles, it might seem. However, the ubiquity of the Internet and its largely de-territorialized nature have brought the issues raised forty years ago into much starker relief. Territoriality's loss of relevance has become far more glaring, and a quest for alternative principles of jurisdictional order is all the more urgent. Therefore, a resurrection, and even upgrade, of the balancing principles of Section 403, is advisable. In Jurisdiction in International Law I have made this point forcefully. ${ }^{10} \mathrm{I}$ deeply regretted that states have come to consider reasonableness as an option rather than an obligation, with the European Court of Justice and the U.S. Supreme Court in the leading international antitrust judgments of the time $(1988,1993)$ readily establishing their jurisdiction on the basis of the territorial principle without much regard to comity. ${ }^{12}$ This vainglorious quest for a territorial nexus to legitimize a jurisdictional assertion, without the need being felt for further jurisdictional inquiry into the appropriateness of the assertion, continues to this very day. The European Court of Justice, for instance, in 2011, considered an aircraft's mere departure from or arrival at an EU airport to satisfy the territorial principle for purposes applying its emissions trading scheme also to the aircraft's mileage beyond the EU airspace. ${ }^{13}$ Most recently, in 2015, and somewhat more implicitly perhaps, the same Court held that EU animal welfare laws also applied to animal transport operations outside the EU, insofar as these had their territorial point of departure within the EU. ${ }^{14}$ In the same year, U.S. authorities brought proceedings against allegedly corrupt foreign FIFA officials on the grounds that they used the U.S. financial system and had some meetings in the U.S.-connections satisfying the U.S. territorial nexus requirements- to further their schemes. ${ }^{15}$ Some authors may consider these decisions as instances of "territorial extension," 16 whereas territoriality may in reality be a thin veneer for the imposition of a state's own views on others. If one wishes to hit a dog, one will always find a stick—-territoriality. Thus, a reasonableness-informed approach to jurisdiction can only be welcomed. ${ }^{17}$

\footnotetext{
${ }^{9}$ Some states explicitly authorize such action. E.g. Belgian authorities, pursuant to Article 88ter of the Belgian Code of Criminal Procedure, are authorized to remotely access (copy) a user's data held in computer systems based abroad, provided that they notify the foreign state. The law does not require that the foreign state consent. Such techniques can be said to be in tension with the prohibition of enforcement jurisdiction.

${ }^{10}$ RYNGAERT, supra note 2, at Chapter 5.

12 Joined Cases 89, 104, 114, 116, 117 \& 125 to 129/85, A Ahlström Osakeyhtiö v. Comm'n, 1988 E.C.R. 5193; Hartford Fire Insurance Co v. California, 509 U.S. 764 (1993).

13 Case C-366/10, Air Transport Association of America and Others v. Secretary of State for Energy and Climate Change (ATA), 2011 E.C.R. I-13755. See further Geert De Baere \& Cedric Ryngaert, The ECJ's Judgment in Air Transport Association of America and the International Legal Context of the EU's Climate Change Policy, 18 Eur. Foreign AfF. REv. 389 (2013).

${ }^{14}$ Case C-424/13, Zuchtvieh-Export GmbH v Stadt Kempten, EU:C:2015:259.

15 See Indictment, United States v. Jeffrey Webb (E.D.N.Y. 2015).

${ }^{16}$ Joanne Scott, Extraterritoriality and Territorial Extension in EU Law, 62 AM. J. CoMP. L. 87 (2014).

${ }^{17} \mathrm{I}$ have to concede that in the two European examples I gave, reasonableness was indirectly applied. Although having obtained the green light of the European Court of Justice, the European Commission refrained from actually applying the Aviation Directive against foreign operators to give multilateral negotiations a chance ("stop the clock"). This could be characterized as "reasonableness after the fact." See Regulation (EU) No 421/2014 of the European Parliament and the Council of 16 April 2014 amending the Directive 2003/87/EC establishing a scheme for greenhouse gas emission allowance trading within the Community, 2014 O.J. (L129) 1. In Zucht$\underline{v i e h}$, the Court held that authorities "had a certain margin of discretion allowing it to take due account of the uncertainties involved in a long journey, part of which was to take place in the territory of third countries" (para. 52). In so doing, it implied that the Directive need perhaps not be applied in full, although it went on to limit this "reasonableness" to cases of conflicts with local legislation (a rather poor understanding of reasonableness in fact).
} 


\section{Incorporating Nonstate Interests In The Jurisdictional Analysis}

The approach to reasonableness does not, and should not, only factor in the interests of states but also of nonstate actors affected by the jurisdictional assertion. Thus, Section 403(d) of the Restatement (Third) draws attention to "the existence of justified expectations that might be protected or hurt by the regulation"; where regulatory subjects (individuals, corporations) could not have anticipated that they would be subject a state's regulation, the application of such regulation may be presumptively unreasonable. This focus on private and not only sovereign interests is a typical feature of private international law, the rules of which aim to confer predictability on cross-border transactions between individuals. Their incorporation into the public international law jurisdictional reasonableness analysis - which may yield a limitation of sovereign rightsdemonstrates a convergence of private and public international law, at least as far as the exercise of jurisdiction is concerned. Svantesson does not fail to highlight this convergence, relying in part on Alex Mills' pioneering work. ${ }^{18}$

The ensuing entwining of public and private international law is not new. It heralds a return to the early $19^{\text {th }}$ century, when, as the work of Joseph Story testifies to, both fields were not yet strictly separated. ${ }^{19}$ Nor is the proposal to take private interests into account new. In fact, it heralds a return to the $17^{\text {th }}$ century "law of nations" in the tradition of Grotius and Suarez, which did not consider the state as the sole subject of international law, but gave agency to the individual as well. This tradition is currently being resurrected by humanitylaw oriented scholars such as Ruti Teitel, who, deeming individuals the central players in the international legal system, ${ }^{20}$ also advocate a law-making and implementation role for nonstate actors. ${ }^{21}$ For the law of jurisdiction, this means that the outer bounds of a jurisdictional assertion should be codetermined by private actors alongside states. Surely, such actors, being the addressees of the regulation, have an interest in it, all the more so when they risk being subject to possibly conflicting multiple regulatory burdens. As far as adjudicatory jurisdiction is concerned, these private interests could easily be brought to the court's attention through party submissions and potentially through third parties' amicus curiae briefs. As far as the exercise of prescriptive jurisdiction is concerned, legislatures may want to solicit the views of affected parties, including private parties, when deliberating the contours of a regulation with "extraterritorial" effects. This regulatory "other-regardingness" has been eloquently set out in the work of Eyal Benvenisti. ${ }^{22}$

\section{Concluding observations}

It goes to Dan Svantesson's credit that he has brought together existing ideas on reform of the law of jurisdiction and lent them particular urgency in light of the challenges posed by the Internet era. His main contribution to the debate is that he suggests to shed territoriality as the jurisdictional linchpin and to replace it with a test based on connection/interests/reasonableness. Such a suggestion may find fertile ground in cyberspace, where the distinction between territoriality and extraterritoriality has largely lost its relevance, and has indeed become a problem in itself. Outside cyberspace, however, I believe territoriality has an abiding role to play, as a convenient shorthand (proxy) for Svantesson's three-pronged test. That being said, territorial exclusivity

18 Alex Mills, Rethinking Jurisdiction in International Law, 84 BRIT. Y.B. INT’́L L. 187 (2014).

${ }^{19}$ Joseph STORY, COMMENTARIES ON THE CONFLICT OF LAWs, ForEIGN AND DOMESTIC (1846).

${ }^{20}$ Ruti G. Teitel, Humanity's LAW 75 (2011) (pointing to a premodern-state understanding of international law subjectivity, in which peoples and individuals played a role alongside states).

${ }^{21} \underline{I d}$. at 171 (noting the opportunity for persons and peoples to shape the law to which they are subject, and to shape the relevant values that are at issue).

22 Eyal Benvenisti, Sovereigns as Truestees of Humanity: On the Accountability of States to Foreign Stakeholders, 107 AJIL 295 (2013). 
is past its heyday, especially when global values and interests are jeopardized. These days, sovereignty entails responsibility. ${ }^{23}$ In particular, where territorial sovereigns fail to take their responsibility to investigate and prosecute international crimes committed on their territory, bystander states, relying in universality, may be allowed to step in. For reasons of ownership, democratic legitimacy, and evidence-taking, it remains nevertheless important that territorial sovereigns are allowed jurisdictional right of way. This is, of course, assuming that the impugned acts are clearly situated in just one territory and are not de-territorialized as in the case of cyberspace. In the latter case, Svantesson's proposal is surely an attractive jurisdictional alternative.

${ }^{23}$ See for a philosophical exploration: JENS BARTELSON, SOVEREIGNTY AS SYMBOLIC FORM (2014). 